\title{
Factors influencing consumer's intention towards e- grocery shopping: An extended technology acceptance model approach
}

\section{Winda Trisna Ryadi (D), Florentina Kurniasari, Kristianus Ade Sudiyono}

Faculty of Business, Universitas Multimedia Nusantara, Boulevard Gading Serpong, Tangerang, Indonesia windaryadi@gmail.com; florentina@umn.ac.id; kristianus.adesudiyono@lecturer.umn.ac.id

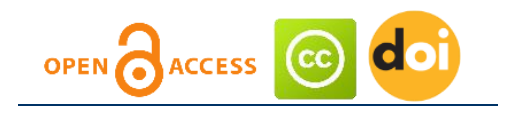

Article history:

Received: September 25, 2021

1st Revision: October 19, 2021

Accepted: November 26, 2021

\section{JEL classification:}

D12

\section{DOI:}

10.14254/jems.2021.6-2.11

\begin{abstract}
The e-grocery industry in Indonesia is multiplying and is expected to become one of the most important markets in the world. Massive amount of funding for e-grocery start-ups, the high desire of Indonesian consumers to buy grocery products online, and COVID19 are increasing the growth of e-grocery services in Indonesia. Although the desire to use e-grocery services in Indonesia is high, data shows that e-grocery adoption is still far below other e-commerce product categories such as fashion and electronics. Previous research and surveys also show that consumers will return to shopping for wholesale products offline and stop/reduce the use of e-grocery after the COVID19 pandemic. Therefore, this research is interested in examining the factors that can increase the adoption of e-grocery in Indonesia. Quantitative research was conducted using the purposive sampling method and obtained 135 respondents who have ever used egrocery service/shopping in the JABODETABEK area. Data were analyzed using PLS-SEM (Partial Least Square - Structural Equation Model). The results of this study indicate that perceived risk has a negative effect on Trust. Social Influence, Perceived Usefulness, and Perceived Ease of Use have a positive effect on Trust. Social Influence and Perceived Ease of Use have a positive effect on Perceived Usefulness. However, it turns out that Trust in this study was not proven to affect the intention to use e-grocery services/shopping for grocery products online.
\end{abstract}

Keywords: TAM, e-grocery, online grocery shopping.

Corresponding author: Winda Trisna Ryadi

E-mail: windaryadi@gmail.com

This open access article is distributed under a Creative Commons Attribution (CC-BY) 4.0 license. 


\section{Introduction}

Shopping for groceries online is relatively new in a developing country like Indonesia. However, considering its vast market potential, Indonesia is predicted to become one of the largest online grocery markets in the world. Before COVID19 online grocery continued to grow significantly, the sales and consumer willingness were high to shop groceries products online (Daily Social, 2020).

Despite the enormous market potential and high sales growth, groceries have the lowest adoption rate compared to other e-commerce categories such as fashion \& electronics (L.E.K Consulting, 2021). COVID19 is accelerating this e-grocery trend, so the adoption of e-grocery in Indonesia is getting higher (The Jakarta Post, 2020). Even research shows that after COVID19 ends, consumers will return to their habit of shopping for groceries offline at offline stores such as markets and supermarkets (Focused, 2020).

For e-grocery companies investing in Indonesia, of course, this will be an obstacle to expansion if consumers return to their old habit of shopping for groceries offline (Kurniasari \& Ryadi, 2021). Therefore, companies need to know what factors can influence consumers to shop for groceries online to adjust their strategies.

In the literature, several factors that may influence the level of e-grocery adoption have been widely discussed, such as fear of fraud, security concerns, lack of trust, and the intangible nature of many online products have prevented consumers from buying online (Gefen et al. 2003; Ranganathan \& Jha 2007 in (Ma, 2021). Chen \& Barnes (2007) in (Ma, 2021) also show that lack of trust prevents online users from participating in e-commerce platforms.

Based on these problem statements, the research questions are: Based on the above problem statement, the research questions are: (1) What factors affect the acceptance of e-grocery among Indonesian consumers? (2) To determine and recognize the most significant factors influencing Indonesian consumers' acceptance of online grocery shopping. So, the purpose of the study is to investigate factors affecting the adoption of e-grocery in Indonesia as a foundation guideline for the e-grocery company to craft their strategies.

\section{Literature review}

\section{Retail Management}

"Retail" comes from the French word "retaillier" which means" to cut a piece off or "break bulk" Retail involves direct interface interactions with customers and the coordination of business activities from start to finish - from the product concept or design stage to offer, customer delivery, and post-delivery service. The retail industry has contributed significantly to the economic growth of many countries and is undoubtedly one of the most rapidly changing and dynamic industries in the world today (Vedamani, 2017).

In retail, either products or services intended for distribution to the final consumer, pass through several business chains or intermediaries. This path to reach the final consumer is called the retail distribution channel. Retailers play an important role in distribution channels, especially in reaching consumers with products and services while at the same time absorbing customer feedback to convey to manufacturers and marketers for necessary product improvements (Vedamani, 2017).

Retail stores are divided into two: organized retail and unorganized retail. Organized retail refers to trading activities carried out by authorized/certified retailers registered under government regulations. They have standard store-wide procedures and are operated under legal entities in a sole proprietorship, a partnership (franchise), or a private limited company (Vedamani, 2017). Organized retail in Indonesia is better known as modern retail, examples of well-known modern retail brands in Indonesia such as Alfamart and Indomaret (minimarkets), Hypermart, and Transmart (supermarkets).

Meanwhile, unorganized retail is better known as traditional retail in Indonesia. This retail business usually does not have specific operational standards, operates on a small scale, and without good operational management, e.g., no sales and income statement record. Examples of unorganized retail in Indonesia include local grocery stores called warung, mom \& pop shops, mobile cart sellers, street vendors, etc.

\section{E-grocery}

E-grocery is business-to-consumer e-commerce, whose primary purpose is selling groceries online, and its business focus is on customer value, shopping convenience, fast delivery to the customer's doorstep or doorstep delivery. Grocery retailers have faced more significant challenges 
than other online retailers since the birth of e-grocery in the early 2000s (Jagani, Oza, \& Chauhan, 2020).

The factors that hinder consumers from using e-grocery of the retail stores are the nature of choosing the grocery products. There are concerns about product quality because of the perishable and perishable nature of grocery products; consumers also do not get the opportunity to check the quality according to their needs and the availability of certain brands and products according to consumers (Jagani et al., 2020). However, despite all the challenges, consumers also feel the benefits of shopping for groceries products online. Grocery shopping is considered stressful due to overcrowding and long queues (Droogenbroeck \& Van Hove, 2021). For consumers who usually buy groceries, this is an activity they do not like. For such consumers, they prefer to buy groceries and other daily necessities online because of the convenience factor provided by e-grocery. The simplicity and speed of online grocery shopping provide other benefits for consumers (Bezirgani \& Lachapelle, 2020).

E-grocery shopping in Indonesia itself is increasing very rapidly, driven by the COVID-19 pandemic. Several e-grocery start-up companies have experienced high growth since implementing large-scale social restrictions (PSBB) at the beginning of the COVID19 pandemic appearing in Indonesia (The Jakarta Post, 2020). However, before COVID19, e-grocery in Indonesia only developed in the major economic and business centers such as Indonesia's capital city Jakarta and major cities around it, namely Bogor, Depok, Tangerang, and Bekasi (JABODETABEK area). Nevertheless, the growth potential is still enormous. Indonesia's online grocery market share is around $0.3 \%$ and will grow to $0.5 \%$ in 2022 . According to the Institute of Grocery Distribution Asia (IGD Asia), in 2022, Indonesia is expected to become the fourth most significant online grocery market in Asia after China, India, and Japan (Nurhayati-Wolff, 2021).

\section{Technology acceptance model (TAM)}

This research aims to measure the factors that will affect Indonesian consumers' level of adoption/acceptance towards e-grocery or online grocery retail.

Therefore, in this study, the author uses the Technology Acceptance Model (TAM) developed by Fred Davis and Richard Bagozzi. Due to its strong characteristics, TAM is the most commonly used model to explain the individual acceptance of a particular information system

TAM introduces two new variables, namely perceived usefulness (PU) and perceived ease of use (PEOU), and proposes it as a significant determinant of attitude toward a particular technology (Park, Amendah, Lee, \& Hyun, 2019).

Despite the high adoption rate, many researchers have since expressed the need for additional variables to provide a more robust model (Legris, Ingham, \& Collerette, 2003). In their extended model, Venkatesh and Davis removed attitude because of the weak attitude in predicting behavioral intention and actual use; and reintroduced subjective norms as external variables (Venkatesh, 2000). This extended model was later known as the TAM2. Another meta-analysis analyzing 145 published studies identified three main factors at the root of the popularity of TAM (Yousafzai, Foxall, \& Pallister, 2007)

First, the model is specifically designed for information technology and as an excellent measure to explain and predict the acceptance of diverse user populations on various technologies in different organizations, cultural contexts, and skill levels. Second, TAM has a well-known theoretical background, is well researched, and provides a validated inventory of measurement scales. Third, because this model is used extensively in countless studies, it has garnered strong empirical support for its explanatory qualities and attributes. Therefore, TAM is considered the most recognized model of user acceptance of technology.

\section{Research model \& hypotheses}

As discussed previously, TAM introduces two new variables: Perceived Ease of Use (PEOU) and Perceived Usefulness (PU), where PEOU can be the predictor of PU. In this study, PEOU is defined as the extent to which consumers believe that shopping for groceries online will be effort-free/very easy; and PU is the extent to which a person believes that shopping for groceries online provides more benefits/benefits (Davis, 1989).

According to several studies in various fields, such as in Ma (2021) in a study that integrates TAM, trustworthiness, perceived risk, and consumer traits to determine the factors that influence the intention of non-adopters using online pharmacies, found that perceived risk has a negative and significant effect on non-adopters with high IT experience (Wu \& Ke, 2015). A study integrating 
personality traits, perceived risk, and the Technology Acceptance Model in online shopping found that perceived risk negatively affects Trust.

Park et al. (2019) found that the customer's perceived risk negatively affects Trust in Mpayment. Research exploring perceived risk and Trust in the context of online payments in China also found that perceived risk negatively affects Trust in online payment technology (Yang, Pang, Liu, Yen, \& Michael Tarn, 2015). Based on the theoretical description above, the authors make a hypothesis for this research as follows:

\section{H1 Perceived Risk (PR) harms Trust (TR)}

A study by Zheng, Chen, Zhang, \& Wang (2020) on the intention to use autonomous vehicles (AV) in China found that social influence is the most vital determinant of Trust. (Alalwan, Baabdullah, Rana, Tamilmani, \& Dwivedi, 2018) also found that social influence is the most vital determinant of Trust in the context of research on intentions to use mobile social networks games in Saudi Arabia. Chaouali, Ben Yahia, \& Souiden (2016), in a study to investigate the intention to use internet banking services in developing countries (Tunisia), found that social influence positively and significantly affects consumer confidence in banks. Based on the theoretical description above, the authors make a hypothesis for this research as follows:

\section{H2 Social Influence (SI) has a positive effect on Trust (TR)}

Singh \& Sinha (2020), in a study to determine the factors that influence a merchant's intention to use mobile wallet technology, found that perceived usefulness positively affects Trust, which is then proven to affect intention. $\mathrm{Wu} \& \mathrm{Ke}$ (2015), in a study that integrates personality traits, perceived risk, and the Technology Acceptance Model in the context of online shopping, found that perceived Usefulness has a significant effect on Trust. (Ventre \& Kolbe, 2020) also found a positive relationship between the Perceived Usefulness of online review and Trust in Mexico's context of online shopping. Park et al. (2019) in a study on the intention to use m-payment, found that perceived Usefulness positively affects Trust in m-payment. Based on the theoretical description above, the authors make a hypothesis for this research as follows:

\section{H3 Perceived Usefulness (PU) has a positive effect on Trust (TR)}

Ma (2021) in a study that integrates TAM, trustworthiness, perceived risk, and consumer traits to determine the factors that influence the intention of non-adopters to use online pharmacies, found that perceived ease of use has a positive effect on non-adopters Trust with high IT experience. Wu \& Ke (2015), in a study that integrates personality traits, perceived risk, and the Technology Acceptance Model in the context of online shopping, found that the effect of perceived ease of use on Trust is positive and significant.

Yang et al., (2015) research that explored TAM, perceived risk and trust in the context of online payments in China also found that perceived ease of use positively affects Trust in online payment technology.

Based on the theoretical description above, the authors make a hypothesis for this research as follows:

\section{H4: Perceived Ease of Use (PEOU) has a positive effect on Trust (TR)}

According to the extended TAM, SI positively correlates to PU (Venkatesh, Thong, \& Xu, 2016). This relationship was confirmed by (Kim, Ma, \& Park, 2009) in a study regarding the readiness of US consumers to adopt mobile technology for fashion products. In the field of e-grocery, the relationship was confirmed by (Driediger \& Bhatiasevi, 2019) in a study regarding the acceptance and usage behavior of online grocery shopping in Thailand. The researcher assumes that consumers will shop for groceries online if they feel that influential people in the surrounding environment think that buying grocery products online is good. The effect of SI used with TAM has also been studied in a meta-analysis that concludes and supports a positive relationship between SI and PU (Schepers \& Wetzels, 2007). In the study, the authors analyzed 51 articles containing 63 studies to evaluate the effect of SI on PU and ITU.

Based on the theoretical description above, the authors make a hypothesis for this research as follows:

H5: Social Influence (SI) has a positive effect on Perceived Usefulness (PU) 
Dhagarra et al. (2020) confirmed the positive effect of perceived ease of use on perceived benefits in a study of online health service adoption in India. Meanwhile, in the context of egrocery/online grocery shopping, several previous studies have also confirmed the positive influence of perceived ease of use on perceived benefits: Driediger \& Bhatiasevi (2019) and (Loketkrawee \& Bhatiasevi, 2018) in e-grocery research in Thailand, Shukla \& Sharma (2018) in e-grocery research in India and (Gutama \& Dewi Intan, 2017) in research on online purchase of vegetables and fruit in Malang, Indonesia.

Based on the theoretical description above, the authors make a hypothesis for this research as follows:

\section{H6: Perceived Ease of Use (PEOU) has a positive effect on Perceived Usefulness (PU)}

Consumers moving from an e-service vendor to another vendor feel that other vendors provide a better offer than the vendor currently used (Dick \& Basu, 1994). A better offer means the consumer perceives a more significant benefit, so he or she is interested in moving. In the case of online grocery shopping, where consumers can easily compare online, the consumer can easily judge which one provides the most benefit (R. Singh \& Rosengren, 2020). The higher the benefits consumers feel in shopping for groceries online, the higher the possibility of their interest in using online grocery shopping. Based on the theoretical description above, the authors make a hypothesis for this research as follows:

\section{H7: Perceived Usefulness (PU) has a positive effect on Behavioral Intention (BI)}

In research on the adoption of e-commerce (Pavlou, 2003) found that the perception of ease of use positively affects an interest in using e-commerce. (Dhagarra et al., 2020) also found similar findings in a study on the adoption of online health services in India. In the context of e-grocery research, the positive influence of Perceived Ease of Use on interest in using e-grocery was found in research by Driediger \& Bhatiasevi (2019) and Chakraborty (2019). Wu \& Ke (2015), in a study that integrates personality traits, perceived risk, and the Technology Acceptance Model in the context of online shopping, found that perceived ease of use has a positive effect on the intention to do online shopping. Based on the theoretical description above, the authors make the following hypothesis:

\section{H8: Perceived Ease of Use (PEOU) has a positive effect on Behavioral Intention (BI)}

(Pavlou, 2003) found that Trust in web retailers positively affects the intention to transact online. (Mou, Shin, \& Cohen, 2017) research results show that Trust is important in the early and late stages of consumer acceptance of online health services. (N. Singh \& Sinha, 2020) in a study to determine the factors that influence a merchant's intention to use mobile wallet technology found that perceived usefulness positively affects Trust, which is then proven to affect intention. Research in Mexico by (Ventre \& Kolbe, 2020) also concluded that Trust positively influences consumer interest in developing countries to shop online. Based on the theoretical description above, the authors make the following hypothesis:

H9: Trust (TR) has a positive effect on Behavioral Intention (BI)

Figure 1: Conceptual framework

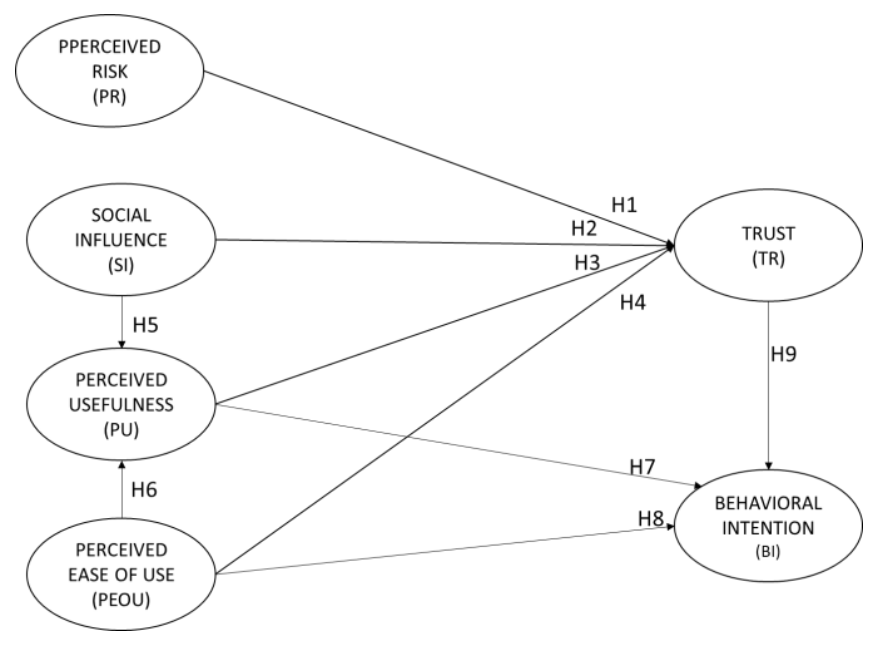




\section{Research methodology}

\section{Quantitative methodology}

To receive many responses and to confirm existing literature on OGS, quantitative research methods were selected for this study. The questionnaire was adopted and modified based on previous research. Instrument development is described further in the following section.

\section{Instrument development}

To ensure validity and allow comparisons between these previous studies and studies, scales and items have been coming from the existing literature. Apart from the Part 1 questionnaire, which asks for demographic and descriptive characteristics, all items were measured using a seven-point Likert scale, ranging from (1) strongly disagree to (7) strongly agree. The second part of this survey was designed to measure the construct of this research. Pilot research with 30 respondents was conducted to test the format, structure, and clarity of questions.

\section{Data collection}

The sample is part of the number and characteristics possessed by the population (Hair, Hult, Ringle, \& Sarstedt, 2017). To determine the sample to be taken from the population, a sampling technique is needed, namely a sampling technique. This study uses a non-probability sampling technique, which is a sampling technique that does not provide equal opportunities or opportunities for each element or member of the population to be selected as a sample. The type of non-probability sampling used in this study is purposive sampling, which is a sampling technique that applies specific criteria or considerations.

The sample of this research is the users of e-grocery services in Indonesia, namely those who have purchased food, beverage, and daily necessities products (groceries), with criteria over 17 years of age and domiciled in the following cities: Jakarta, Bogor, Depok, Tangerang, dan Bekasi (JABODETABEK). This sample was chosen because those who have used e-grocery services tend to be more able to judge objectively by recalling their experiences when shopping for groceries products online. The age limit of 17 years is used because it is considered an adult and can make decisions based on its considerations and is the minimum age limit for having an identity card in Indonesia. JABODETABEK was chosen because it is the primary market for e-grocery services in Indonesia. In this region, the development of e-grocery is very rapid compared to other areas because it is an economic and business center that is seen as more ready to receive e-grocery services (The Jakarta Post, 2020)

After determining the research sample, it is necessary to determine the minimum number of samples needed to process research data. A practical guide often used in determining the minimum sample size is ten times the maximum number of arrows pointing to latent variables anywhere in the PLS pathway model (Hair et al., 2017). With the number of arrows pointing at the latent variables in this study, there were 9 , so the number of samples needed was 9 × $10=90$.

\section{Data analysis \& findings}

\section{Outer model analysis (convergent $\&$ discriminant validity)}

Evaluation of the measurement model or outer model is carried out to assess the validity and reliability. This study uses an outer model with reflexive indicators to evaluate the validity test with convergent and discriminant validity, while the reliability test usesCronbach's Alfa and Composite Reliability.

\section{Inner model testing result}

This study wants to examine the relationships that have been formulated previously based on the theory of Technology Acceptance Model 2 (TAM2) and integrate other variables relevant to Indonesian consumers, namely the perceived risk and trust variables; to know what factors ultimately affect consumer interest in buying grocery products through online channels. Since this research extends the Technology Acceptance Model (TAM) theory, the method used to test the hypotheses proposed in this study is Partial Least Squares - Structural Equation Modeling (PLS- 
SEM). Hair et al. (2011) in Ghozali (2021) recommend using PLS-SEM if the research is an exploratory or extension of the existing structural theory.

The relationships tested in this study include:

- The influence of perceived risks, social influence, Perceived Usefulness, and perceived ease of use variables on Trust

- The effect of social influence and perceived ease of use on perceived Usefulness

- The influence of perceived Usefulness perceived ease of use and trust variables on behavioral intention.

According to (Hair et al., 2017), when using PLS-SEM, the primary evaluation criteria for the structural model are the R2 measures and the level of significance of the path coefficients. Accordingly, the R2 should be high concerning the research discipline. Since this paper aims to explain consumer behavior and acceptance, an R2 value of 0.20 is considered high. As described in Table 6 , the model allocates $26.2 \%$ of the variance to intention to use, $38.1 \%$ of the variance to perceived Usefulness, and $46.7 \%$ of the variance to trust. All R2 values are statistically significant.

The result of this study is not entirely in accordance with the technology acceptance model (TAM) because only Perceived Usefulness has been shown to affect behavioral intention; in the context of the study is the interest in buying groceries products online. Meanwhile, perceived ease of use (PEOU) does not affect the intention to use e-grocery.

\begin{tabular}{lcrrr} 
Table 1: Outer model analysis result & $\begin{array}{c}\text { Cronbach's } \\
\text { Alpha }\end{array}$ & rho_A & $\begin{array}{c}\text { Composite } \\
\text { Reliability }\end{array}$ & $\begin{array}{c}\text { Average } \\
\text { Variance } \\
\text { Extracted } \\
\text { (AVE) }\end{array}$ \\
\hline BEHAVIORAL INTENTION & 0.713 & 0.793 & 0.823 & 0.609 \\
PERCEIVED EASE OF USE & 0.813 & 0.830 & 0.877 & 0.642 \\
PERCEIVED RISKS & 0.853 & 0.879 & 0.899 & 0.690 \\
PERCEIVED USEFULNESS & 0.844 & 0.860 & 0.890 & 0.619 \\
SOCIAL INFLUENCE & 0.857 & 0.870 & 0.903 & 0.701 \\
TRUST & 0.852 & 0.862 & 0.895 & 0.631
\end{tabular}

Table 2: Inner model evaluation result - path coefficient (Mean, STDEV, T-values, P Values)

\begin{tabular}{|c|c|c|c|c|}
\hline & $\begin{array}{c}\text { Sample } \\
\text { Mean (M) }\end{array}$ & $\begin{array}{l}\text { Standard } \\
\text { Deviation } \\
\text { (STDEV) }\end{array}$ & $\begin{array}{l}\text { T Statistics } \\
\text { (|O/STDEV|) }\end{array}$ & P Values \\
\hline PERCEIVED EASE OF USE $\rightarrow$ BEHAVIORAL INTENTION & 0.207 & 0.134 & 1.510 & 0.132 \\
\hline PERCEIVED EASE OF USE $\rightarrow$ PERCEIVED USEFULNESS & 0.494 & 0.083 & 6.023 & 0.000 \\
\hline PERCEIVED EASE OF USE $\rightarrow$ TRUST & 0.243 & 0.096 & 2.485 & 0.013 \\
\hline PERCEIVED RISKS $\rightarrow$ TRUST & -0.224 & 0.060 & 3.583 & 0.000 \\
\hline PERCEIVED USEFULNESS $\rightarrow$ BEHAVIORAL INTENTION & 0.274 & 0.113 & 2.249 & 0.025 \\
\hline PERCEIVED USEFULNESS $\rightarrow$ TRUST & 0.361 & 0.087 & 4.236 & 0.000 \\
\hline SOCIAL INFLUENCE $\rightarrow$ PERCEIVED USEFULNESS & 0.214 & 0.073 & 2.838 & 0.005 \\
\hline SOCIAL INFLUENCE $\rightarrow$ TRUST & 0.156 & 0.066 & 2.273 & 0.023 \\
\hline TRUST $\rightarrow$ BEHAVIORAL INTENTION & 0.139 & 0.109 & 1.312 & 0.190 \\
\hline
\end{tabular}


Figure 2: Path Coefficient - T statistic

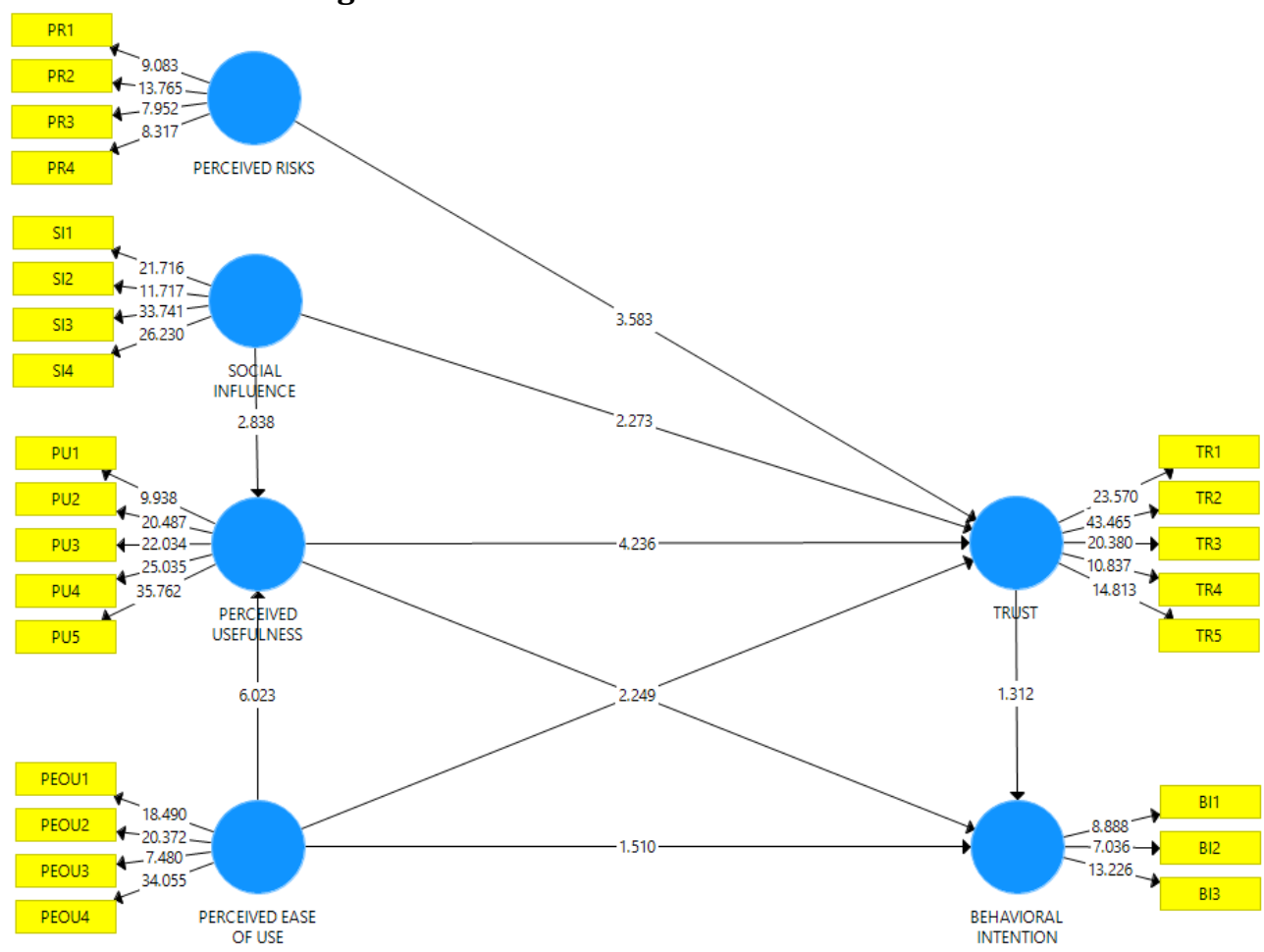

\section{Table 3: Inner model evaluation result - $\mathrm{R}$ square value}

\begin{tabular}{lcc}
\hline & R Square & R Square Adjusted \\
\hline BEHAVIORAL INTENTION & 0.262 & 0.245 \\
PERCEIVED USEFULNESS & 0.381 & 0.372 \\
TRUST & 0.467 & 0.451
\end{tabular}

Figure 3: Path coefficient - R-square

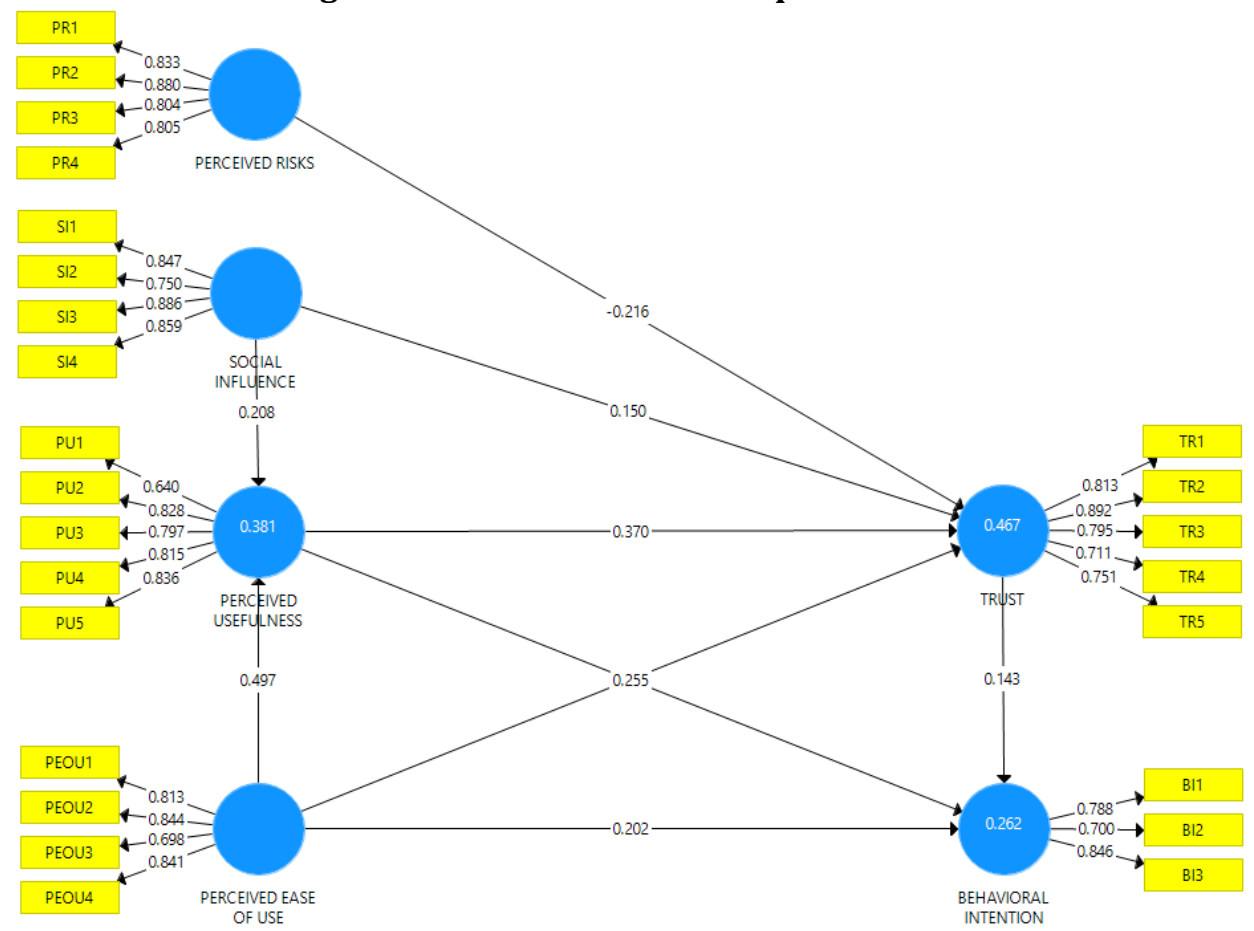




\section{Conclusion}

\section{Discussion}

From the research results obtained the following conclusions:

Table 4 Summary of
hypotheses test
\begin{tabular}{|c|l|c|}
\hline \multicolumn{2}{|c|}{ Hipotesis } & Result \\
\hline $\mathrm{H} 1$ & $\mathrm{PR} \rightarrow \mathrm{TR}(-)$ & accepted \\
\hline $\mathrm{H} 2$ & $\mathrm{SI} \rightarrow \mathrm{TR}$ & accepted \\
\hline $\mathrm{H} 3$ & $\mathrm{PU} \rightarrow \mathrm{TR}$ & accepted \\
\hline $\mathrm{H} 4$ & $\mathrm{PEOU} \rightarrow \mathrm{TR}$ & accepted \\
\hline $\mathrm{H} 5$ & $\mathrm{SI} \rightarrow \mathrm{PU}$ & accepted \\
\hline $\mathrm{H} 6$ & $\mathrm{PEOU} \rightarrow \mathrm{PU}$ & accepted \\
\hline $\mathrm{H} 7$ & $\mathrm{PU} \rightarrow \mathrm{BI}$ & accepted \\
\hline $\mathrm{H} 8$ & $\mathrm{PEOU} \rightarrow \mathrm{BI}$ & rejected \\
\hline $\mathrm{H} 9$ & TR $\rightarrow \mathrm{BI}$ & rejected \\
\hline
\end{tabular}

- H1 Perceived Risks have a negative and significant effect on Trust

The results of the hypothesis test show that it has a T value of more than 1.96 (3.961) and a $P$ value of less than $0.05(0.000)$, so that perceived risks (PR) have a positive and significant effect on trust, and $\mathrm{H} 1$ is accepted.

According to (Chen, Yan, Fan, \& Gordon, 2015), the relationship between trust and perceived risk is controversial, and empirical findings regarding their relationship are different/various results. Some argue that perceived risk affects trust, while others suggest an inverse direction of causality, i.e., trust affects perceived risks (Wu \& Ke, 2015; Yang et al., 2015). This study confirms that perceived risk is a predictor of trust and can be explained by the" "threshold model" (Gefen, Benbasat, \& Pavlou, 2008).

Here, trust is considered a reducer of perceived risk and negatively affects perceived risk. That is, if the level of trust exceeds the perceived risk threshold, consumers tend to participate in online transactions. On the other hand, if the perceived risk exceeds the level of trust, consumers may be averse to taking risks and rejecting transactions.

\section{- H2 Social Influence has a positive and significant effect on Trust}

The hypothesis test results show that $\mathrm{H} 2$ is accepted because it has a T value of more than 1.96 (2.172) and a P value of less than $0.05(0.03)$ so that Social Influence has a positive and significant effect on trust.

This study follows the results of a study that examined consumer intentions to adopt AV in China (Zheng et al., 2020). China, like Indonesia, is a country with a collectivistic solid culture where individual decisions are more likely to be influenced by the opinions/views of others.

In terms of buying groceries online, which is an entirely different experience than buying other product categories, someone will have more confidence when they see that people around them are already using them, either through advice or social media. This conclusion is supported by the respondents" answers to the SI2 indicator, where the majority strongly agree that they often see people using e-grocery services on social media.

\section{- H3 Perceived Usefulness has a positive and significant effect on Trust}

The hypothesis test results show that H3 is accepted because it has a T value of more than 1.96 (4.104) and a P value of less than $0.05(0.00)$, so Perceived Usefulness has a positive and significant effect on trust.

This study follows the research results by (Ventre \& Kolbe, 2020), which examined the effect of the perceived usefulness of online reviews on consumer trust. (Park et al., 2019) and (N. Singh \& Sinha, 2020) found that perceived usefulness positively and significantly affects trust in $\mathrm{m}$ payment/m-wallet providers (Wu \& Ke, 2015) found that PU has a positive and significant effect on online shopping intentions. 
This study proves that the perceived benefits of using e-grocery provide consumers with a clear advantage over offline grocery shopping so that the perceived benefits can lead to consumer confidence. It can be seen in the respondents" answers that the biggest benefits they feel from buying grocery products online are saving time, saving money, and being convenient.

\section{- H4 Perceived Ease of Use has a positive and significant effect on Trust}

The hypothesis test results show that $\mathrm{H} 4$ is accepted because it has a T value of more than 1.96 $(2,405)$ and a $P$ value of less than $0.05(0.02)$, so Perceived Usefulness has a positive and significant effect on trust. The results of this study are in accordance with the research. The results of this study are in accordance with research (Ma, 2021), (Yang et al., 2015), and (Wu \& Ke, 2015) that perceived ease of use of technology can increase someone's trust.

(Crawford, 2003) found that ease of internet pharmacies use, such as access to drug-related information, online consultation with pharmacists, real-time order tracking, customized services, can contribute to consumer confidence.

\section{- H5 Social influence has a positive and significant effect on Perceived Usefulness}

The hypothesis test results show that H5 is accepted because it has a T value of more than 1.96 (2.789) and a P value of less than $0.05(0.01)$ so that social influence has a positive and significant effect on perceived usefulness. The results of this study are in accordance with the results of research (Venkatesh and Davis, 2000), Schepers and Wetzels (2007), and (Driediger \& Bhatiasevi, 2019).

\section{- H6 Perceived Ease of Use has a positive and significant effect on Perceived Usefulness}

The hypothesis test results show that H6 is accepted because it has a T value of more than 1.96 $(6,048)$ and a P value of less than $0.05(0.00)$, so Perceived Ease of Use has a positive and significant effect on perceived usefulness. The more consumers feel that online shopping is easy or free of effort, the higher the benefits felt by consumers. The result of this study is in accordance with TAM and confirmed in the following researches: (Dhagarra et al., 2020), (Driediger \& Bhatiasevi, 2019), (Loketkrawee \& Bhatiasevi, 2018), (Shukla \& Sharma, 2018), and (Gutama \& Intan, 2017) in research on online vegetable and fruit buying interest in Malang, Indonesia.

\section{- $\quad$ H7 Perceived Usefulness has a positive and significant effect on Behavioral Intention}

The hypothesis test results show that $\mathrm{H} 7$ is accepted because the T value is more than 1.96 (2.145) and a P value of less than 0.05 (0.03), so Perceived Ease of Use has a positive and significant influence on intention to use e-grocery. The results showed that perceived usefulness contributed significantly to the intention to use OGS, meaning that consumers who felt that shopping for groceries online was helpful, the greater their interest in shopping for groceries online.

The results also show that perceived usefulness contributes more to intention to use than perceived ease of use. The results of this study are in accordance with the research of (Sherah Kurnia, 2003) in e-grocery research in Australia; (Hui \& Wan, 2009) in online grocery research in Singapore; (Driediger \& Bhatiasevi, 2019) in e-grocery research in Thailand and (Chakraborty, 2019) and (Shukla \& Sharma, 2018) in e-grocery research in India.

\section{- H8 Perceived Ease of Use does not affect Behavioral Intention}

The hypothesis test results show that H8 is rejected because the T value is less than 1.96 (1.564) and a P-value of more than 0.05 (0.119).

The results of this study are in accordance with the results of research by (Ma 2021) and (Gefen et al., 2008), who also found that PEOU is not proven to affect Behavioral Intention directly but must go through Perceived Usefulness (PU) first. It is proofed in H6 that PEOU has a positive and significant effect on PU, positively affecting the intention to shop for groceries products online.

(Amin, Rezaei, \& Tavana, 2015) also found that PEOU did not affect BI. Ease of use and a userfriendly website is essential for consumers" first purchases, but that is not what determines shopping interest. This result may be related to today's e-commerce websites, which are generally very well designed, feature-rich, and have developed various functions to facilitate consumer ease of use. So when considering shopping for groceries products online, consumers may not perceive PEOU as a motivator but need to evaluate further other aspects of buying drugs online.

\section{- H9 Trust does not affect Behavioral Intention}

The hypothesis test results show that H9 is rejected because it has a T value of less than 1.96 (1.343) and a P-value of more than $0.05(0.180)$. This result means that although someone has confidence in the e-grocery vendor, this does not necessarily lead to an intention to use the e-grocery service. 
This finding is confirmed by (Suebtimrat \& Vongai, 2021) which also found that trust did not affect behavioral intention in a study investigating intentions to use QR code payments and did not affect the intention to use a mobile wallet in Singapore (Seetharaman, Kumar, Palaniappan, \& Weber, 2017)

(Ma, 2021) examined the factors that influence the intention to use online pharmacies showed that trust in BI was moderated by age, where this effect was significant for younger consumers (under 30 years) not significant for older consumers (over 30 years old). (Kian, Loong, \& Fong, 2019) also found that older consumers tend to face more barriers due to tradition and perceived risk and are less likely to shop online. This study also has the majority of respondents aged over 30 years.

Trust does not affect Behavioral Intention, perhaps because younger consumers tend to show a higher level of trust in online services (Liébana-Cabanillas, Sánchez-Fernández, \& Muñoz-Leiva, 2014). In contrast, older consumers reported having more concerns regarding the security and privacy of online transactions (Laukkanen, 2016). This can reduce older consumers' trust in evendors (e-grocery in this study) and further discourage them from using internet-based services.

\section{Implication}

The results of this study indicate that perceived Usefulness is the only factor that directly influences intention because perceived ease of use and Trust in this study were not proven to affect the intention to use e-grocery services. At the same time, the factors that can affect perceived Usefulness are perceived ease of use and social influence. Based on the results of the following research is a discussion of managerial implications aimed at e-grocery business actors in Indonesia:

- To increase social influence, companies can apply many-to-many marketing strategies that give consumers or potential customers a solid reason to share information about the company's brand with their circle. Examples of many-to-many strategies are referral codes, group buying, affiliate marketing.

- Information or content shared with the public must focus on perceived ease of use and usefulness, and integrated solid marketing communication is needed. Irrelevant messages shared by users will not increase people's intention to use e-grocery.

- To increase the benefits perceived by consumers, the company can focus on creatively communicating the benefits proven in this research that consumers feel, namely: save time, save money, and convenience.

\section{Limitation \& suggestions}

The researcher realizes that there are several limitations in this study:

- This study has an R2 of 0.262 for behavioral intention so that $73.8 \%$ of other factors that can influence behavioral intention still have to be considered.

- There are still few journals and supporting theories that integrate TAM, perceived risk, and Trust in one study, so that researchers find it difficult to find supporting statements for each indicator.

- Researchers discuss the use of e-grocery in general.

Further research can use theories other than TAM to understand e-grocery adoption in Indonesia, for example, UTAUT. Further research can also discuss the factors that might moderate the influence of PEOU, PU, and Trust on the intention to remember. Research (Ma, 2021) found that the strength and weakness of the relationship of Trust to intention are influenced by age and gender.

Based on these research limitations, below are the suggestions for future research.

a) Further research can use theories other than TAM to understand e-grocery adoption in Indonesia, for example, UTAUT.

b) Further research can also discuss the factors that might moderate the influence of PEOU, PU, and Trust on the intention to remember. Research $(\mathrm{Ma}, 2021)$ found that the strength and weakness of the relationship of Trust to intention are influenced by age and gender.

c) This research model can be applied to sub-categories of industries that are also relatively new but will develop in Indonesia, such as e-fishery (a shopping application for marine products through a digital platform).

d) The respondents of this study are adopters of online grocery in Indonesia. To complement this research in the future, non-adopters respondents can understand the critical factors that influence their interest in starting to use e-grocery/online grocery shopping.

Considering that groceries products have an extensive product range, the categories of groceries products sold in e-grocery applications such as perishable (perishable) and non-perishable 
(non-perishable) may affect buying interest. Therefore, this variable may be applied to understand better whether the grocery product category affects consumer shopping interest.

\section{Funding}

The author(s) received no financial support for the research, authorship, and/or publication of this article.

\section{Declaration of conflicting interests}

The author(s) declared no potential conflicts of interest with respect to the research, authorship, and/or publication of this article.

\section{Citation information}

Gracia, \& Kurnia, R. (2021). The determinant factors affecting auditors' ability to detect fraud: Empirical study at public accounting firms in Jakarta and Tangerang. Economics, Management and Sustainability, 6(2), 132-145. doi:10.14254/jems.2021.6-2.10.

\section{Reference}

Alalwan, A. A., Baabdullah, A. M., Rana, N. P., Tamilmani, K., \& Dwivedi, Y. K. (2018). Examining adoption of mobile internet in Saudi Arabia: Extending TAM with perceived enjoyment, innovativeness and trust. Technology in Society, 55, 100-110. https://doi.org/10.1016/j.techsoc.2018.06.007

Amin, M., Rezaei, S., \& Tavana, F. S. (2015). Gender differences and consumer's repurchase intention: The impact of trust propensity, usefulness and ease of use for implication of innovative online retail. International Journal of Innovation and Learning, 17(2), 217-233. https://doi.org/10.1504/IJIL.2015.067409

Bezirgani, A., \& Lachapelle, U. (2020). Qualitative Study on Factors Influencing Aging Population's Online Grocery Shopping and Mode Choice When Grocery Shopping in Person. Transportation Research Record, 2675(1), 79-92. https://doi.org/10.1177/0361198120964790

Chakraborty, D. (2019). Indian Shoppers' Attitude Towards Grocery Shopping Apps: A Survey Conducted on Smartphone Users. Metamorphosis: A Journal of Management Research, 18(2), 83-91. https://doi.org/10.1177/0972622519885502

Chaouali, W., Ben Yahia, I., \& Souiden, N. (2016). The interplay of counter-conformity motivation, social influence, and trust in customers' intention to adopt Internet banking services: The case of an emerging country. Journal of Retailing and Consumer Services, 28, 209-218. https://doi.org/10.1016/J.JRETCONSER.2015.10.007

Chen, Y., Yan, X., Fan, W., \& Gordon, M. (2015). The joint moderating role of trust propensity and gender on consumers' online shopping behavior. Computers in Human Behavior, 43, 272-283. https://doi.org/10.1016/j.chb.2014.10.020

Crawford, S. Y. (2003). Internet Pharmacy: Issues of Access, Quality, Costs, and Regulation. Journal of Medical Systems, 27(1), 57-65. https://doi.org/10.1023/A:1021009212905

Daily Social. (2020). Menakar Masa Depan Startup “Online Grocery” di Indonesia. Retrieved from https://dailysocial.id/post/online-grocery-startup-indonesia

Davis, F. D. (1989). Perceived Usefulness, Perceived Ease of Use, and User Acceptance of Information Technology. MIS Quarterly, Vol. 13(No. 3), 319-340 (22 pages). Retrieved from https://doi.org/10.2307/249008

Dhagarra, D., Goswami, M., \& Kumar, G. (2020). Impact of Trust and Privacy Concerns on Technology Acceptance in Healthcare: An Indian Perspective. International Journal of Medical Informatics, 141(April), 104164. https://doi.org/10.1016/j.ijmedinf.2020.104164

Dick, A. S., \& Basu, K. (1994). Customer loyalty: Toward an integrated conceptual framework. Journal of the Academy of Marketing Science, 22(2), 99-113. https://doi.org/10.1177/0092070394222001

Driediger, F., \& Bhatiasevi, V. (2019). Online grocery shopping in Thailand: Consumer acceptance and usage behavior. Journal of Retailing and Consumer Services, 48(February), 224-237. https://doi.org/10.1016/j.jretconser.2019.02.005 
Droogenbroeck, E. Van, \& Van Hove, L. (2021). Adoption and usage of E-grocery shopping: A contextspecific UTAUT2 model. Sustainability (Switzerland), https://doi.org/10.3390/su13084144

Focused, C. (2020). Shopper Sentiments: A September 2020 Global Mood Survey. Retrieved from https://us.moodmedia.com/2020-shopper-sentiment/

Gefen, D., Benbasat, I., \& Pavlou, P. A. (2008). A research agenda for trust in online environments. Journal of Management Information Systems, 24(4), 275-286. https://doi.org/10.2753/MIS0742-1222240411

Gutama, W. A., \& Dewi Intan, A. P. (2017). Consumer Acceptance Towards Online Grocery Shopping in Malang, East Java, Indonesia. Agricultural Social Economic Journal, 17(1), 23-32. https://doi.org/10.21776/ub.agrise.2017.017.1.4

Hair, J. F., Hult, G. T. M., Ringle, C. M., \& Sarstedt, M. (2017). A Primer on Partial Least Squares Structural Equation Modeling (PLS-SEM) (Second Edi). SAGE Publications Ltd.

Jagani, K., Oza, F. V., \& Chauhan, H. (2020). Customer Segmentation and Factors Affecting Willingness to Order Private Label Brands: An E-Grocery Shopper's Perspective. https://doi.org/10.4018/978-1-7998-0257-0.ch011

Kian, T. P., Loong, A. C. W., \& Fong, S. W. L. (2019). Customer Purchase Intention on Online Grocery Shopping. International Journal of Academic Research in Business and Social Sciences, 8(12). https://doi.org/10.6007/ijarbss/v8-i12/5260

Kim, J., Ma, Y. J., \& Park, J. (2009). Are US consumers ready to adopt mobile technology for fashion goods?: An integrated theoretical approach. Journal of Fashion Marketing and Management, 13(2), 215-230. https://doi.org/10.1108/13612020910957725

Kurniasari, F., \& Ryadi, W. T. (2021). Determinants of Indonesian E-Grocery Shopping Behavior After Covid-19 Pandemic Using the Technology Acceptance Model Approach. United International Journal for Research \& Technology (UIJRT), 03(01), 12-18.

L.E.K Consulting. (2021). Covid-19 a catalyst for growth in Indonesia's e-grocery market. Retrieved from https://www.consultancy.asia/news/3941/covid-19-a-catalyst-for-growth-inindonesias-e-grocery-market

Laukkanen, T. (2016). Consumer adoption versus rejection decisions in seemingly similar service innovations: The case of the Internet and mobile banking. Journal of Business Research, 69(7), 2432-2439. https://doi.org/10.1016/j.jbusres.2016.01.013

Legris, P., Ingham, J., \& Collerette, P. (2003). Why do people use information technology? A critical review of the technology acceptance model. Information and Management, 40(3), 191-204. https://doi.org/10.1016/S0378-7206(01)00143-4

Liébana-Cabanillas, F., Sánchez-Fernández, J., \& Muñoz-Leiva, F. (2014). Antecedents of the adoption of the new mobile payment systems: The moderating effect of age. Computers in Human Behavior, 35(December), 464-478. https://doi.org/10.1016/j.chb.2014.03.022

Loketkrawee, P., \& Bhatiasevi, V. (2018). Elucidating the Behavior of Consumers toward Online Grocery Shopping: The Role of Shopping Orientation. Journal of Internet Commerce, 17(4), 418-445. https: //doi.org/10.1080/15332861.2018.1496390

Ma, L. (2021). Understanding non-adopters' intention to use internet pharmacy: Revisiting the roles of trustworthiness, perceived risk and consumer traits. Journal of Engineering and Technology Management - JET-M, $59 \quad$ (December https://doi.org/10.1016/j.jengtecman.2021.101613

Mou, J., Shin, D. H., \& Cohen, J. F. (2017). Trust and risk in consumer acceptance of e-services. Electronic Commerce Research, 17(2), 255-288. https://doi.org/10.1007/s10660-015-92054

Nurhayati-Wolff, H. (2021). Market share of online grocery retail in Indonesia in 2020 with a forecast for 2022. Retrieved from https://www.statista.com/statistics/1227268/indonesia-onlinegrocery-retail-market-share/

Park, J., Amendah, E., Lee, Y., \& Hyun, H. (2019). M-payment service: Interplay of perceived risk, benefit, and trust in service adoption. Human Factors and Ergonomics In Manufacturing, 29(1), 31-43. https://doi.org/10.1002/hfm.20750

Pavlou, P. A. (2003). Consumer acceptance of electronic commerce: Integrating trust and risk with the technology acceptance model. International Journal of Electronic Commerce, 7(3), 101134. https://doi.org/10.1080/10864415.2003.11044275 
Schepers, J., \& Wetzels, M. (2007). A meta-analysis of the technology acceptance model: Investigating subjective norm and moderation effects. Information \& Management, 44(1), 90-103. https://doi.org/10.1016/J.IM.2006.10.007

Seetharaman, A., Kumar, N. K., Palaniappan, S., \& Weber, G. (2017). Factors Influencing Behavioural Intention to Use the Mobile Wallet in Singapore. Journal of Applied Economics and Business Research JAEBR, 7(2), 116-136.

Shukla, A., \& Sharma, S. K. (2018). Evaluating Consumers' Adoption of Mobile Technology for Grocery Shopping: An Application of Technology Acceptance Model. Vision SAGE Publications, 22(2), 185-198. https: //doi.org/10.1177/0972262918766136

Singh, N., \& Sinha, N. (2020). How perceived trust mediates merchant's intention to use a mobile wallet technology. Journal of Retailing and Consumer Services, 52(June 2019), 101894. https://doi.org/10.1016/j.jretconser.2019.101894

Singh, R., \& Rosengren, S. (2020). Why do online grocery shoppers switch? An empirical investigation of drivers of switching in online grocery. Journal of Retailing and Consumer Services, 53(June 2019), 101962. https://doi.org/10.1016/j.jretconser.2019.101962

Suebtimrat, P., \& Vongai, R. (2021). An Investigation of Behavioral Intention Towards QR Code Payment in Bangkok, Thailand. Journal of Asian Finance, Economics and Business, 8(1), 939950. https://doi.org/10.13106/jafeb.2021.vol8.no1.939

The Jakarta Post. (2020). Online grocery shopping to drive e-commerce growth as PSBB reimposed: Experts. Retrieved from https://www.thejakartapost.com/news/2020/09/14/onlinegrocery-shopping-to-drive-e-commerce-growth-as-psbb-reimposed-experts.html

Vedamani, G. G. (2017). Retail Management (5th editio). Pearson India Education Services Pvt. Ltd.

Venkatesh, V. (2000). Determinants of perceived ease of use: integrating control , intrinsic motivation , acceptance model. Inorganic Chemistry Communications, 11(3), 319-340.

Ventre, I., \& Kolbe, D. (2020). The Impact of Perceived Usefulness of Online Reviews, Trust and Perceived Risk on Online Purchase Intention in Emerging Markets: A Mexican Perspective. Journal of International Consumer Marketing, 32(4), 287-299. https://doi.org/10.1080/08961530.2020.1712293

Wu, W. Y., \& Ke, C. C. (2015). An online shopping behavior model integrating personality traits, perceived risk, and technology acceptance. Social Behavior and Personality, 43(1), 85-98. https://doi.org/10.2224/sbp.2015.43.1.85

Yang, Q., Pang, C., Liu, L., Yen, D. C., \& Michael Tarn, J. (2015). Exploring consumer perceived risk and trust for online payments: An empirical study in China's younger generation. Computers in Human Behavior, 50, 9-24. https://doi.org/10.1016/J.CHB.2015.03.058

Yousafzai, S. Y., Foxall, G. R., \& Pallister, J. G. (2007). Technology acceptance: a meta-analysis of the TAM: Part 1. In Journal of Modelling in Management (Vol. 2). https://doi.org/10.1108/17465660710834453

Zheng, Q., Chen, J., Zhang, R., \& Wang, H. H. (2020). What factors affect Chinese consumers' online grocery shopping? Product attributes, e-vendor characteristics and consumer perceptions. China Agricultural Economic Review, 12(2), 193-213. https://doi.org/10.1108/CAER-092018-0201

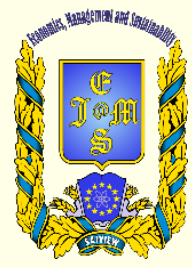

() 2016-2021, Economics, Management and Sustainability. All rights reserved.

This open access article is distributed under a Creative Commons Attribution (CC-BY) 4.0 license.

You are free to:

Share - copy and redistribute the material in any medium or format Adapt - remix, transform, and build upon the material for any purpose, even commercially.

The licensor cannot revoke these freedoms as long as you follow the license terms.

Under the following terms:

Attribution - You must give appropriate credit, provide a link to the license, and indicate if changes were made

You may do so in any reasonable manner, but not in any way that suggests the licensor endorses you or your use.

No additional restrictions

You may not apply legal terms or technological measures that legally restrict others from doing anything the license permits.

Economics, Management and Sustainability (ISSN: 2520-6303) is published by Scientific Publishing House "CSR",

Poland, EU and Scientific Publishing House "SciView", Poland

Publishing with JEMS ensures:

- Immediate, universal access to your article on publication

- High visibility and discoverability via the JEMS website

- Rapid publication

- Guaranteed legacy preservation of your article

- Discounts and waivers for authors in developing regions

Submit your manuscript to a JEMS at http://jems.sciview.net or submit.jems@sciview.ne

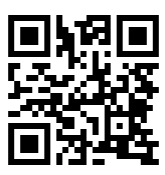

